\title{
Factors Affecting the Use of Shared Space and Environmental Facilities of Cibeureum Rental Social Housing, Indonesia
}

\author{
Hartanto Budiyuwono ${ }^{1}$ \\ ${ }^{1}$ Lecturer of Architecture Program, UNPAR, Bandung, Indonesia \\ Correspondence: Hartanto Budiyuwono, Parahyangan Catholic University, Jl. Ciumbuleuit 94, Bandung, Indonesia. \\ E-mail: hh2611833@gmail.com
}

\author{
Received: June 25, 2019 Accepted: July 16, 2019 Online Published: August 7, 2019 \\ doi:10.5539/res.v11n3p65 \\ URL: https://doi.org/10.5539/res.v11n3p65
}

\begin{abstract}
Shared space and environmental facilities the primary supporting space for low-income residents identical to high social activities. However, in reality, some areas tend not used. This phenomenon indicates exist of other factors that influence its use. This study aims to define the factors that affect the use of shared space and environmental facilities at Cibeureum Rental Social Housing. This research uses the qualitative method by evaluating the use of space and explanation of its phenomenon with the qualitative explanation based on field theory and fact. Factors that affect the use of shared space and environmental facilities of the Cibeureum Rental Social Housing according to research conducted is suitability of the pattern of use of space residents as apply tradition settled and ability of its physical elements in accommodating activities. Users are still doing the action to meet the primary needs of people (clothing, food, and housing) and social events with special needs although space is far from occupancy, because simple social activities at a very close distance to the dwelling. Users are often doing optional activities such as relaxing and sitting are often performed in the nearest space to the dwelling. This research can develop the design of shared space and environmental facilities to consider the distance and type of activities based on suitability of occupant-based traditions of living.
\end{abstract}

Keywords: shared space, environmental facilities, usage, rental social housing

\section{Introduction}

Bandung city in the early 20th century almost became hoofdstad (capital) of the Dutch East Indies replace Batavia has a long historical roots. Bandung's travel span as a city that be said to begin on September 25, 1810. On that date, the 6th Bupati of Bandung R.A. Wiranatakusumah II (1794-1829) emerged as the initiator formation of Bandung City. Wiranatakusumah II initiative is indirectly accelerated from the Dutch colonial government, through besluit issued by the Governor General H.W. Daendels (Colombin, Freek. 2005). The population growth of Bandung was originally closely related to the existing Railway Transportation which built around 1880 by the Dutch hindia connecting city of Bandung with Jakarta (formerly Batavia) (Ekajati, Edi Suhardi. Hardjasaputra. Mardiana. Ietje. 1985).

In 1941 there were 226,877 inhabitants of this city (Oey, E. 2001). Then after the events known as Long March Siliwangi (Pusdatin. 2016), population of this city again increased where in 1950 recorded population of 644,475 people (Sariyun, Y. Martodirdjo, HS. 1993). After independence of Indonesia in 1945, Bandung became the capital of West Java province in Indonesia. Until now in 2018, the total population of Bandung city reached 2.877.185 inhabitants (Permendagri. 2016).

Population growth and development of the city, until now many developed construction of houses for the entire community up to 8 floors high building. Cibeureum Rental Social Housing is a complex of flats which consists of two types of building typology with environmental facilities and a supporting shared space in Cimahi City, West Java, Indonesia. This rental social housing role as a move for Cimahi residents living in urban squatter areas. Cibeureum Rental Social Housing capacity of 371 units, consisting of 297 units with one bedroom and 74 units with two bedrooms. What distinguishes both building topologies is the number of bedrooms, the use of inner court or atrium, and the layout. Typology of a one-bedroom building using the inner court (Fig. 1, Fig. 3), while in units with two bedrooms using atrium (Fig. 2, Fig. 3). Both also have different spatial arrangements.

\section{Methodology and Materials}

Cibeureum Rental Social Housing, Indonesia surveyed and completed two years. The method used is a qualitative method, based on surveys of buildings in the form of photo documentation. And also carried out with questions to users. These questions carried out in the morning around 7:00 a.m. to 9:00 p.m., the afternoon around 17:00 to 19:00 with the aim of 
being able to meet with the residents before or after returning home from work. In addition to asking the workers, they also asked their partners (the wives or even husbands who happened to not work).

The number of questions is about 10 percent of the total number of families. These questions conducted to find out the desires, hopes, or complaints about the place of residence. The results of these questions were together, then discussed, presented in several discussion teams guided by several doctors, and analyzed based on relevant literature guidelines.

Cibeureum Rental Social Housing is a complex of flats which consists of two types of building typology with environmental facilities and a supporting shared space in Cimahi City, West Java, Indonesia. This rental social housing role as a move for Cimahi residents living in urban squatter areas. Cibeureum Rental Social Housing capacity of 371 units, consisting of 297 units with one bedroom and 74 units with two bedrooms. What distinguishes both building topologies is the number of bedrooms, the use of inner court or atrium, and the layout. Typology of a one-bedroom building using the inner court (Fig. 1, Fig. 3), while in units with two bedrooms using atrium (Fig. 2, Fig. 3). Both also have different spatial arrangements.
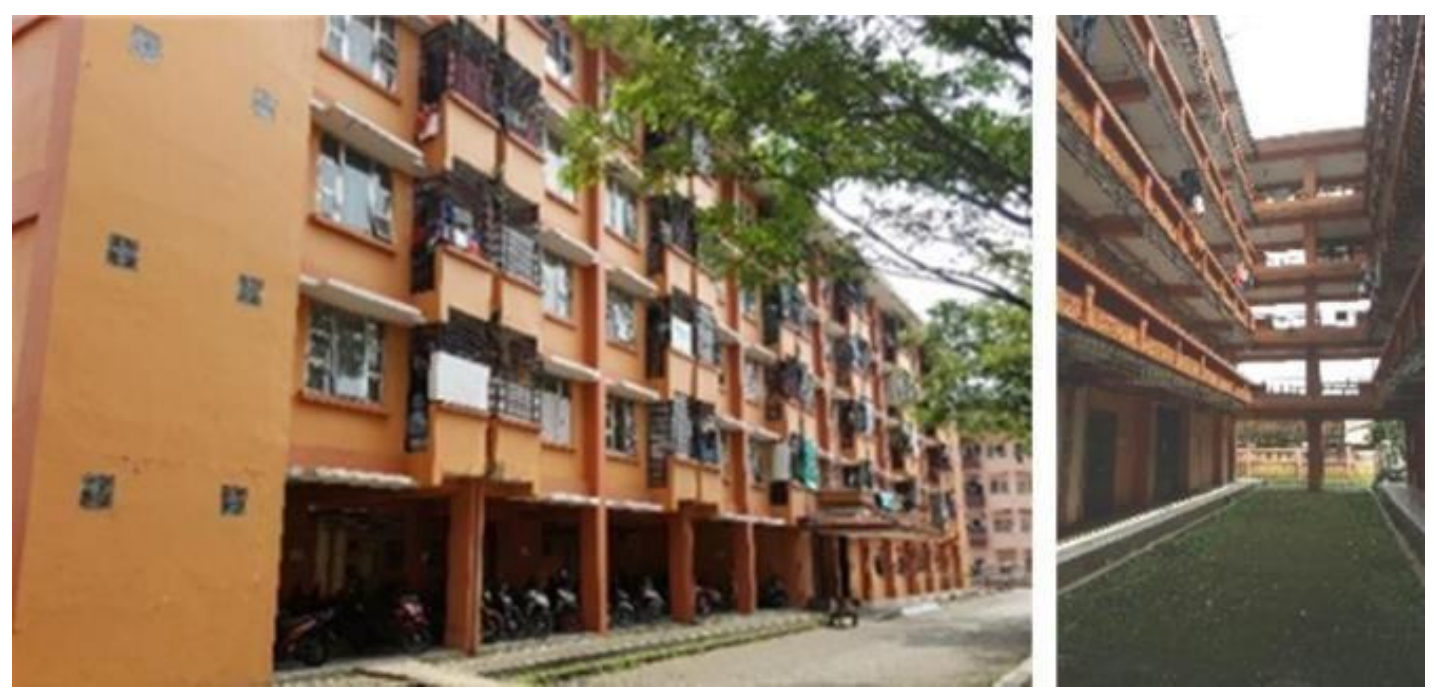

Figure 1. One bedroom building typology of Cibeureum Rental Social Housing (unit 24) using the inner court
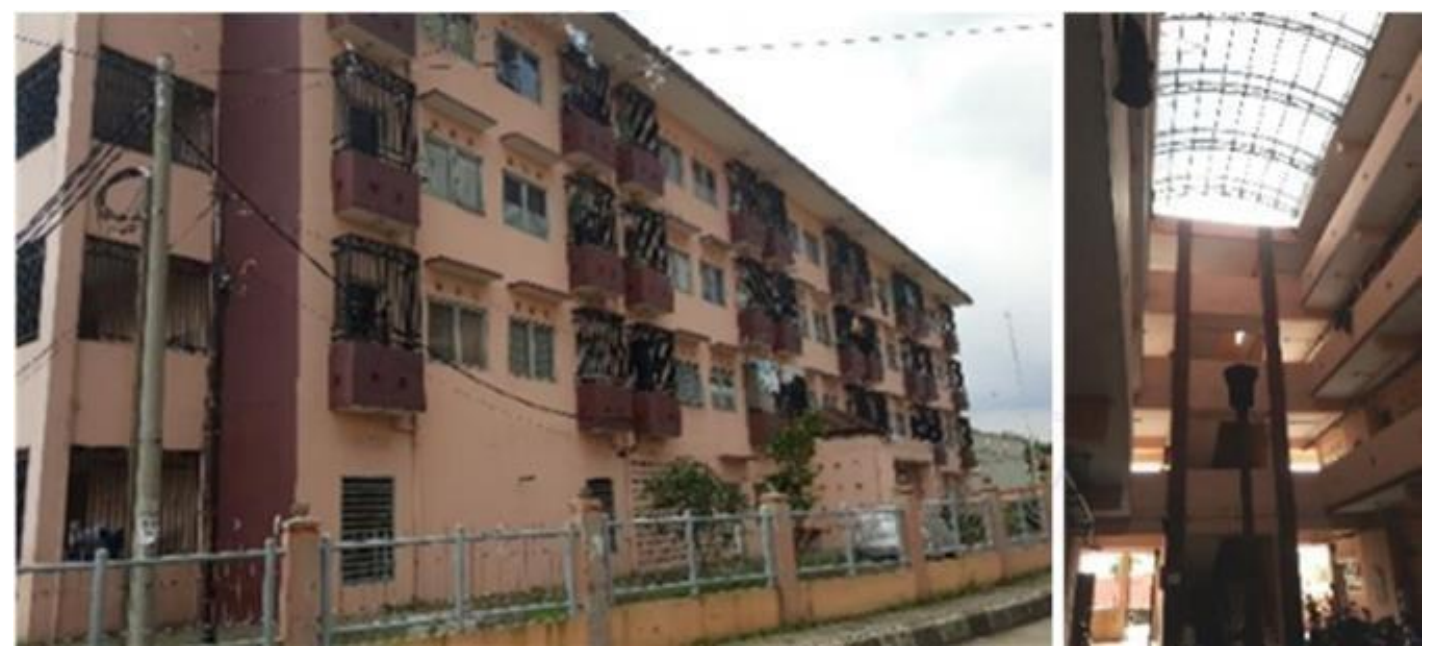

Figure 2. Two bedroom building typology of Cibeureum Rental Social Housing (unit 27) using the atrium 


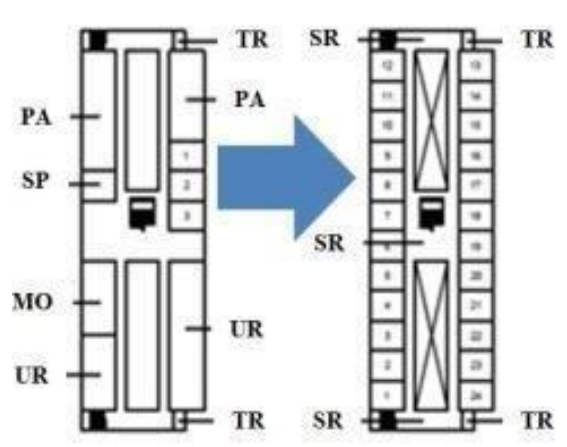

1 st floor typical floor

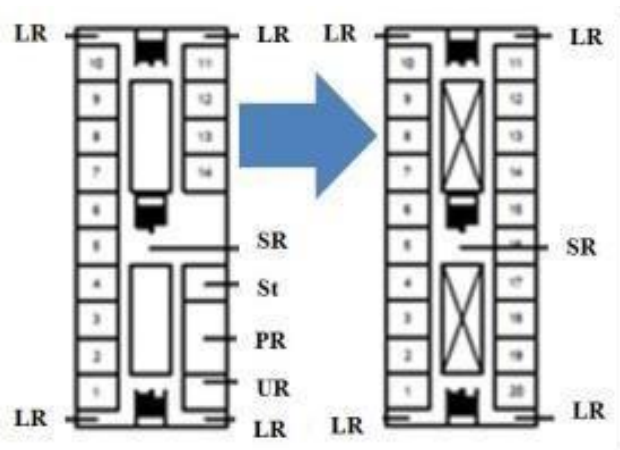

$\mathrm{PA}=$ Parking Area $\mathrm{SP}=$ Shaped Function $\mathrm{MO}=$ Management Office Shaped Function UR = Utility Room TR = Trash Room $\mathrm{PA}=$ Parking Area $\mathrm{SR}=$ Social Room $\mathrm{JR}=\mathrm{L}$ aundry Room $\mathrm{St}=$ Storage Room LR $=$ Laundry room $\mathrm{PR}=$ Prayer Room

Figure 3. Floor plan of unit 24 and unit 27 of Cibeureum Rental Social Housing

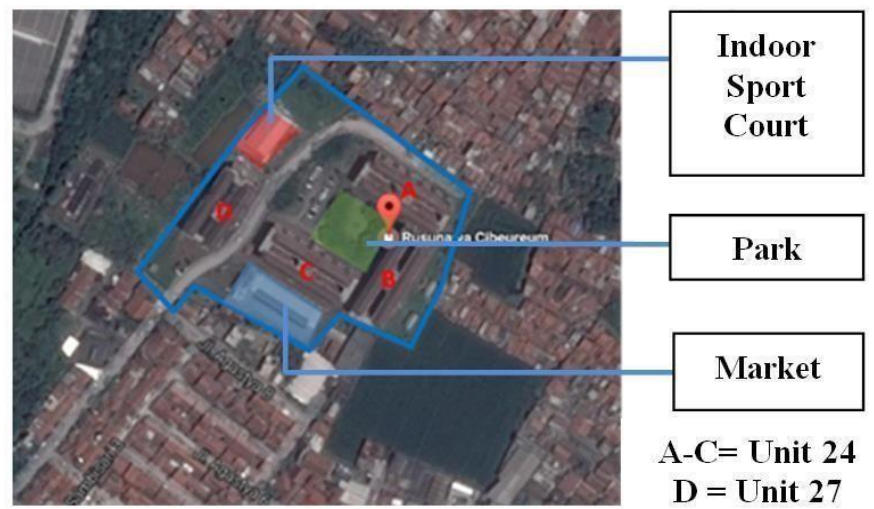

Figure 4. On-site environmental facilities of Cibeureum Rental Social Housing (Google Earth, March 2017)

\section{Results and Discussion}

\subsection{Shared Spaces and Environmental Facilities in Cibeureum Rental Social Housing}

Shared space is a container that accommodates the activities of togetherness by users both positive and negative in meeting economic, social, and cultural needs. The shared space, according to earlier research, be placed close to the dwelling, excluding the corridor within it, and has the requirements be easy in access, free insight, separated with the circulation space, and open-air nuances (Darmiwati, Ratna. 2000).

The lifestyle and tradition of living inhabitants also influence the use of shared space. The shared space in earlier research refers to the social area, where social activities in corridors suggested accommodated in the social space, so that corridor space considered not as a shared space. Circulation about the degree of publicity tends more private than environmental facilities, as well as a sense of ownership of the occupants of the area based on their control making circulation space as part of a shared space. Therefore, the shared room of the Cibeureum Rental Social Housing consists of social rooms, corridors, stairs, and laundry room (two-bedroom residential buildings).

Rental social housing environmental facility is function of life support for residents on economic, social, and cultural aspects (SNI. 2004). Environmental facilities consist of trade facilities, education, health, worship, government and public services, and open space. These spaces can either on-site or integrated with residential buildings (SNI. 2004). Environmental facilities at Cibeureum Rental Social Housing consist of the park, indoor sports court, market, atrium, inner court, and prayer room.

\subsection{Theory of Human Activity in a Space}

Space is a container that accommodates human activities where life takes place (Frick, Heinz. Suskiyanto, FX . Bambang. 2007). Human activities in Living cultures that are likely to work on space users in the Cibeureum Rental Social Housing are Sundanese residents traditions, low-income communities, and village communities, based on the origin, economic level, and previous residence of the inhabitants (Altman, I. 1976). The culture of living in the Sundanese community is inherent with the concept of a landed house that has a yard other than residential spaces within a building (Rossi, M. 1982). 
Sundanese is a traditional society that lives a long time especially in West Java, including the Bandung city, and has a lifestyle, specific procedures (Salura, Purnama. 2015) (Salura, Purnama. 2007).

The tradition living in low-income communities has a high sense of togetherness and simplicity (Thompson, Elizabeth Kendall. 1975). The tradition living in the village community move together with the people around him because of the bonds of brotherhood (Darmiwati, Ratna. 2000) area consisting of necessary, optional, or social activities (Farida, 2013). The necessary activity is an everyday activity and be done under any circumstances as it is a need so that the physical space does not affect us (Cho. Lee. 2011). The optional activity is an activity that occurs when area makes it possible to do so it is highly dependent on the physical space (Gehl, Jan. 1987). Social activity is an activity that requires others be done so that the material of space affects exist of this activity, although not as much as in the optional activity (Gehl, Jan. 1987). Also, settled traditions may also affect the design of shared spaces and environmental facilities as they influence the shape of the activity it occupies (Antariksa. 2011).

\subsection{The Activity in Shared Spaces and Environmental Facilities in Cibeureum Rental Social Housing}

Activities that occur in the shared room and environmental facilities of Cibeureum Rental Social Housing will reviewed based on the character, frequency, scale, suitability of space, and distance from residential units (Purwanto, Edi. Wijayanti. 2012). Also, activities grouped by type to explore the activity relationships with the space they contain (Table 1).

Table 1. Activity in Shared Spaces and Environmental Facilities in Cibeureum Rental Social Housing

\begin{tabular}{|c|c|c|c|c|c|c|c|}
\hline \multirow[t]{3}{*}{ Room } & \multicolumn{5}{|c|}{ Activity } & \multirow{3}{*}{$\begin{array}{l}\text { Conformity } \\
\text { with the } \\
\text { Designation of } \\
\text { Space }\end{array}$} & \multirow{3}{*}{$\begin{array}{c}\text { Distance } \\
\text { from } \\
\text { Dwelling } \\
\text { Unit }\end{array}$} \\
\hline & Hourly to Daily & \multirow[t]{2}{*}{ Weekly to Monthly } & \multirow[t]{2}{*}{ Type } & \multirow[t]{2}{*}{ Characteristic } & \multirow[t]{2}{*}{ Scale } & & \\
\hline & & & & & & & \\
\hline Park & Sitting relaxing (rarely used) & \multirow[t]{4}{*}{-} & Optional & \multirow[t]{2}{*}{ Formal } & \multirow[t]{3}{*}{ Complex } & Planned & Far \\
\hline Market & Buying and selling activities & & Necessary & & & & \\
\hline Indoor sports court & Playing futsal & & Social & Formal & & Planned & \\
\hline \multirow[t]{2}{*}{ Player room } & Pray. Religious activity & & Necessary & & \multirow[t]{5}{*}{ Block } & & Moderate \\
\hline & - & Social gathering & \multirow[t]{4}{*}{ Social } & \multirow{4}{*}{ Informal } & & Unplanned & \\
\hline \multirow[t]{2}{*}{ Atrium } & Playing (children) & - & & & & & \\
\hline & ( & $\begin{array}{l}\text { Social garhering, wedding } \\
\text { reception, watching movie }\end{array}$ & & & & & \\
\hline Inner court & Playing (children, rarely used) & \multirow[t]{7}{*}{-} & & & & & \\
\hline Stairs & \multirow[t]{2}{*}{ Walking } & & \multirow[t]{2}{*}{ Necessary } & \multirow[t]{2}{*}{ Formal } & \multirow[t]{6}{*}{ Floor } & \multirow[t]{2}{*}{ Planned } & Near \\
\hline \multirow[t]{3}{*}{ Corridor } & & & & & & & \multirow[t]{3}{*}{ Very near } \\
\hline & Sitting, relaxing & & Optional & \multirow{4}{*}{ Informal } & & \multirow{3}{*}{ Unplanned } & \\
\hline & Chatting, playing (children) & & \multirow[t]{2}{*}{ Social } & & & & \\
\hline Social room & Playing (children, rarely used) & & & & & & Near \\
\hline Laundry room & Doing laundry & & Necessary & & & Planned & \\
\hline
\end{tabular}

3.4 The Factors Affecting the Usage of Shared Spaces and Environmental Facilities in Cibeureum Rental Social Housing

Based on the analysis conducted, the activity on the rental social housing Cibeureum consists of four groups, the activities of the primary needs of humans, social activities with special needs, simple social activities, and optional activities. The principal human needs activity has the necessary type of activity. Simple and social events with special needs have a kind of social activity. Optional activity has an optional type of activity. Space that is far from occupancy has a tendency used for activities related to the primary human needs (clothing, food, and housing) such as buying and selling transactions in the market (Fig. 5) and another necessity of life. Besides, it also accommodates social activities that must particular space such as playing futsal (futsal is an indoor soccer sports) (Fig. 6) and morning exercise together (vast area). Futsal is an indoor ball game, which played by two teams each consisting of five people using ball manipulation techniques with legs and limbs other than hands with the aim of putting the ball into the opponent's goal (Riadi, Muchlisin. 2018). 


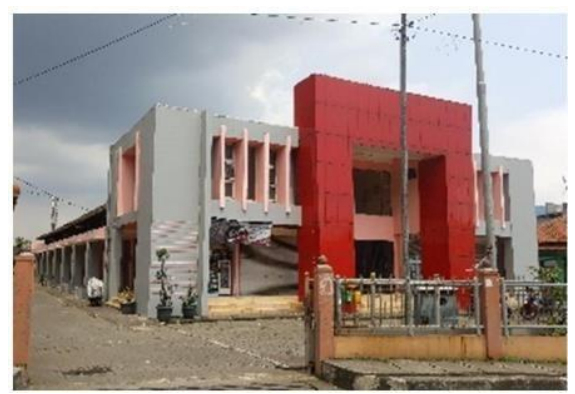

Figure 5. Market as a space to do transactions mainly about life necessity

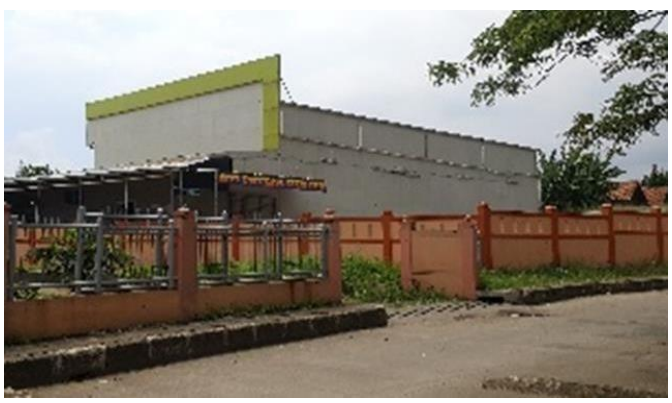

Figure 6. Indoor sport court as a space to play futsal

Simple social events such as sitting and relaxing tend to be rarely done at this distance. Unplanned activity at this range is a joint morning exercise caused by the difficulty of finding a place as large as a parking area on the market to do this action. Also, on the road, on the perimeter of the park, children often play ball, while the park itself is rarely used (Fig. 7).

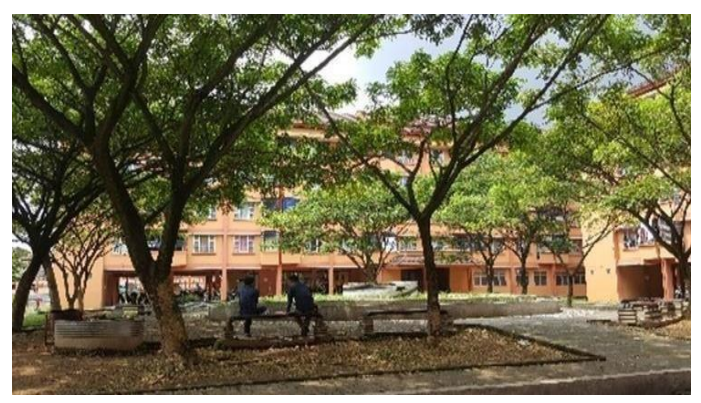

Figure 7. Park which is rarely used, children often play ball on the road at the park's perimeter

Space that is at a moderate distance from occupancy has a tendency used for everyday activities such as worship and social events that must particular space (ample space) such as community meetings, wedding receptions, and watching together, even if only incidental. Informal activities that occur are social activities that must a spacious space. Those events happen because no space can accommodate also the atrium and the praying room because, also extensive enough, space must also be shaded and covered (Fig. 8). Spaces that are close to occupancy have a tendency used for activities related to the primary human needs such as drying clothes and feeding the child (Fig. 9).Informal activities that occur associated with activities to meet the principal needs of humans because of the lack of dwelling space that forces residents to use the surrounding space, the corridor. Besides, there are also simple and optional social activities like relaxing and chatting. The users also do those events in the hallway for the same reason. Both of these phenomena occur because the living tradition influences, the habit of owning a landed house that usually has a yard makes residents feel the corridor is his. 


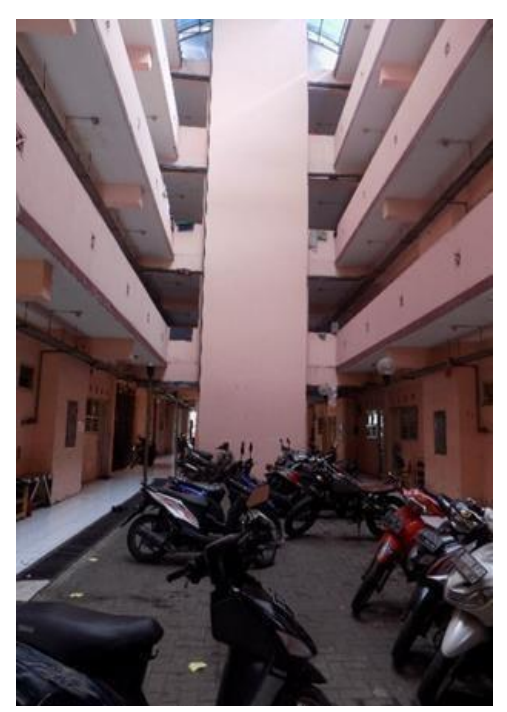

Figure 8. Atrium space which often used for social events that must ample space (when residents are watching together, the projector shoots the stair core)

Moreover, simple living habits from the tradition living is low-income communities also affect how to meet the needs of living in a small residential unit that is by invading the hallway which is the nearest space from residence to meet the needs of their life. The nearest unit's resident from the laundry room dominates the use of it (Fig. 10). Other residents can also use it with permission from the closest dwelling unit which is an agreement among residents.
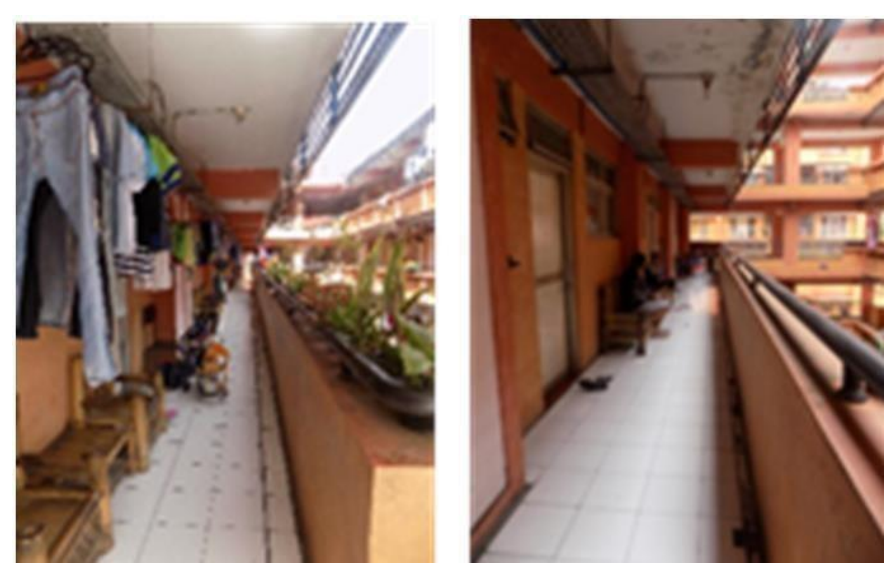

Figure 9. Informal activity in the corridor of Cibeureum Rental Social Housing 

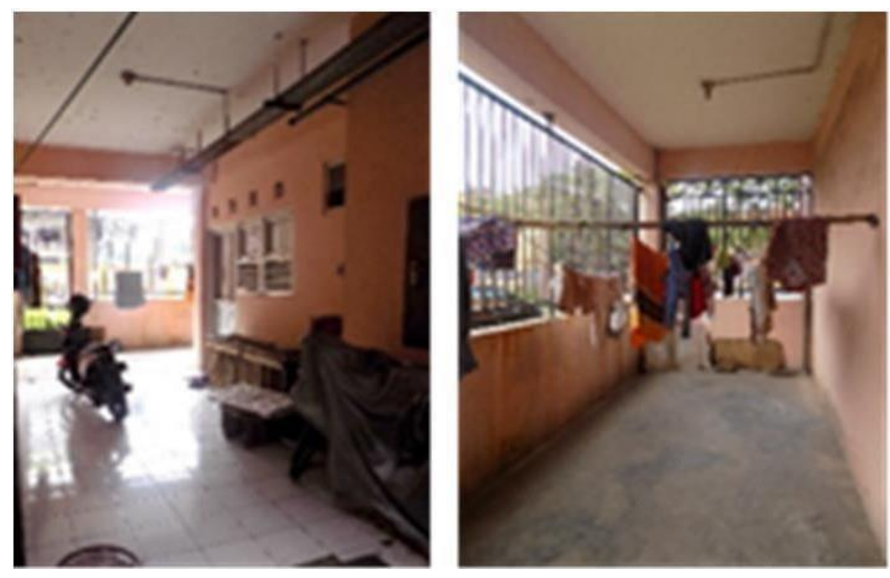

Figure 10. Domination particular resident on the laundry room based on distance to the unit

People rarely use the park, inner court, and social space. All those areas are less suited to the use of space inhabitants as the living traditions and physical elements are not able to accommodate the activities that occur. The park that the most suitable space for morning sports activities is inadequately resulting in the transfer of functions to other areas. The inner court consists of vegetation space that makes it space that accommodates simple social activities is less right according to the pattern of space use because it explain less close to the dwelling (Fig. 11). Simple social events tend to very close to occupancy mainly due to the togetherness of tradition of living.

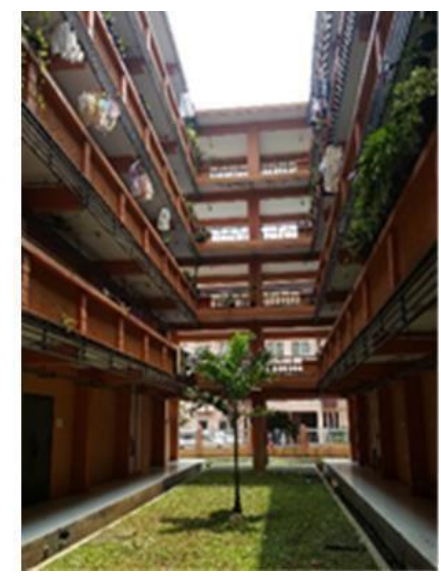

Figure 11. Vegetation on the inner court space

\section{Conclusions}

- Factors that affect the use of shared space and environmental facilities of Cibeureum Rental Social Housing according to research conducted is the suitability tradition settled and the ability its physical elements in accommodating activities.

- Activities to meet the primary needs of people (clothing, food, and housing) and social activities with special needs will still be done although space is far from occupancy, where simple social activities at a very close distance to the dwelling in Cibeureum Rental Social Housing.

- People are often doing optional activities such as relaxing and sitting in the closest space to the dwelling in Cibeureum Rental Social Housing.

\section{References}

Altman, I. (1976). The Environment and Social Behavior. Monterey, CA. Wadsworth

Antariksa. (2011). Pengaruh Kebudayaan dan Adat Istiadat Masyarakat Dalam Permukiman Tradisional. The IJHSS: May Issue'18. Fast Publication. Globally Indexed.

Cho, L. (2011). A study on building sustainable communities in high rise and high density apartments-focused on living program. Building and Environment, 46, 1428-1435. https://doi.org/10.1016/j.buildenv.2011.01.004 
Colombin, F. (ed). (2005). Old Town. New Town: History of Cities in Indonesia Before and After Independence. Yogyakarta: p.188.

Darmiwati, R. (2000). Studi Ruang Bersama dalam Rumah Susun Bagi Penghuni Berpenghasilan Rendah, Dimensi Teknik Arsitektur, 28(2), 114-122.

Ekajati, E. S., Hardjasaputra, S., \& Mardiana, I. (1985). Sejarah Kota Bandung 1945-1979. Departemen Pendidikan dan Kebudayaan Direktorat Sejarah dan Nilai Tradisional. Proyek Inventarisasi dan Dokumentasi Sejarah Nasional.

Farida. (2013). Effect of Outdoor Shared Spaces on Social Interaction in Housing Estate in Algeria. Frontier of Architectural Research, 2, 457-467. https://doi.org/10.1016/j.foar.2013.09.002

Frick, H., Suskiyanto, F. X., \& Bambang. (2007). Dasar- Dasar Arsitektur Ekologi. Yogyakarta: Kanisius.

Gehl, J. (1987). Life Between Buildings. London: Island Press.

Oey, E. (2001). Java. Tuttle Publishing. ISBN 962-593-244-5. Permendagri. (2016). http://www.bandung.go.id, () Copyright.

Purwanto, E. W. (2012). Pola Ruang Komunal di Rumah Susun Bandarharjo Semarang, Dimensi Teknik Arsitektur, 39(1), 23-30. https://doi.org/10.9744/dimensi.39.1.23-30

Pusdatin. (2016). http://www.kemendagri.go.id/pages/profil-daerah/kabupaten/id/32/name/jawa- barat/detail/3273/kotabandung.

Riadi, M. (2018). Lapangan, Peraturan dan Teknik Bermain Futsal. https://www.kajianpustaka.com/2018/06/lapanganperaturan-dan-teknik-bermain-futsal.html

Rossi, M. (1982). The Architecture of The City. Cambridge Mass: MIT Press. Cambridge.

Salura, P. (2007). Menelusuri Arsitektur Masyarakat Sunda. CSS Publishing.

Salura, P. (2015). Sundanese Architecture. PT Rosda International.

Sariyun, Y., \& Martodirdjo, H. S. (1993). Pembinaan disiplin dilingkungan masyarakat kota di Jawa Barat. Departemen Pendidikan dan Kebudayaan. Direktorat Jenderal Kebudayaan. Direktorat Sejarah dan Nilai Tradisional.

SNI. (2014). Badan Standarisasi Nasional. SNI 03-7013-2004: Tata Cara Perencanaan Fasilitas Lingkungan Rumah Susun Sederhana. Bandung: Standar Nasional Indonesia.

Thompson, E. K. (1975). Apartments. Townhouses and Condominiums. New York: McGraw-Hill Book Company.

\section{Copyrights}

Copyright for this article is retained by the author(s), with first publication rights granted to the journal.

This is an open-access article distributed under the terms and conditions of the Creative Commons Attribution license (http://creativecommons.org/licenses/by/4.0/). 